\title{
Eventbetjentuddannelsen \\ - en forskningsbaseret uddannelse i dialogbaseret håndtering af masseforsamlinger
}

\author{
Af Jonas Havelund, Kristian Rasmussen \& Lise Joern ${ }^{1}$
}

\begin{abstract}
This paper describes a specially designed, research-based training programme focused on the policing of mass events. The "Event police training programme" is based on recent research on crowd psychology, i.e., understanding crowd processes, dynamics and the role of other stakeholders' interactions with the masses. Research has found that a misinterpretation of the crowd has often been a contributory cause of riots in connection with mass gatherings, as the tendency has been to adopt a tactic based on an undifferentiated and simplistic view of the crowd. The Event police training programme aims to provide a differentiated understanding of mass groups and encourage the police to reflect on their own behavioural role in the management of these gatherings. This paper describes the background and structure of the Event police training programme."
\end{abstract}

\section{Indledning}

Den 2. juni 1992 blev der afholdt folkeafstemning om Maastrichttraktaten. Afstemningen resulterede i et nej. Året efter, den 18. maj 1993, kom det til en ny folkeafstemning. Denne gang omkring den såkaldte Edinburghaftale, som indeholdt fire danske forbehold i forhold til Maastrichttraktaten. Samme aften udviklede en demonstration på Nørrebro sig til de voldsomste uroligheder i Danmark nogensinde mellem demonstranter og dansk politi, hvor demonstranter blandt andet kastede med brosten og molotovcocktails, mens politiet svarede igen ved at affyre 113 skud, der resulterede i, at 11 demonstranter efterfølgende måtte behandles for skudsår.

Ser man nærmere på urolighederne, finder man en anderledes polititaktisk håndtering af begivenhederne, end vi ser i dag. Blandt andet foregik politiets fremrykning mod demonstranter skulder ved skulder bag deres primære beskyt-

* Title in English: Event police training: A research-based training programme on the policing of mass events. 
telse på gadeniveau, skjolde. Da undersøgelseskommissionen afgav beretning om sagen, blev politiets taktik omtalt som en afgørende faktor for forløbet, idet kommissionen bemærkede, at:

En mere hurtig og fleksibel taktik fra Københavns Politi kunne derfor muligvis have medført et andet begivenhedsforløb på Nørrebro 18.-19. maj 1993. Efter 18.-19. maj 1993 har Københavns Politi i lighed med andre politikredse anskaffet et nyt radiokommunikationssystem, ligesom Københavns Politi har anskaffet nye udrykningskøretøjer med henblik på en mere fleksibel anvendelse af indsatte politienheder. ${ }^{2}$

Efter urolighederne på Nørrebro udviklede dansk politi, med tidligere chefpolitiinspektør Kai Vittrup som nøgleperson, det Mobiltaktiske Indsatskoncept (nu $»$ Mobile Indsatskoncept «, i daglig tale $» M I K \ll)$. Konceptet findes beskrevet i Vittrups bøger Strategi og Operation. ${ }^{3}$ Inspirationen til konceptet stammer fra Holland, der oprindeligt havde udviklet det som et paramilitært indsatskoncept i forbindelse med Hollands status som kolonimagt. Det mobile indsatskoncepts militære struktur kommer til udtryk gennem centrale begreber som: Optisk føring, optisk følge, sektorpatrulje, rapid reaction, anholdelsesgreb og forsvarsformationer, sluse og visitation, dobbelt omfatning, rensning af plads, rydning af barrikade for demonstranter, kile etc. Alt er gennemgået og trænet ned til mindste detalje som en del af uddannelsen i det mobile indsatskoncept. Konceptet er integreret på nationalt plan og er centreret omkring brugen af indsatsvogne, der anvendes til opnåelse af indsatsens strategiske og taktiske mål. Det mobile indsatskoncept har især vist sig effektivt ved politiets håndtering af store demonstrationer og såkaldte "højrisiko « fodboldkampe. Modsat Nørrebrourolighederne, der udstillede de danske betjentes mangel på beskyttelse, føler betjentene sig trygge ved det mobile indsatskoncept, blandt andet fordi kampuniformen og indsatsvognene kan mindske personskader. ${ }^{4}$

I 2008 fremkom Rigspolitiet med National håndbog for den politimaessige indsats i forbindelse med fodboldkampe, der udover fodboldområdet også sigter på håndteringen af større begivenheder såsom demonstrationer. Håndbogen lægger blandt andet vægt på en høj grad af fleksibilitet og tolerance over for alle fodboldtilskuere og rummer implicit et oplæg til en dialogsøgende indsats. På mange måder lægger håndbogens intentioner op til nytænkning inden for håndteringen af fodboldfans, og som vi har påpeget $\mathrm{i}$ anden sammenhæng har implementeringen af håndbogens intentioner ikke været lige nem. ${ }^{5}$ Håndbogens oplæg til ændringer inden for området er således i vid udstrækning blevet fortolket ind i det mobile indsatskoncepts mere konfrontative struktur. 
Meget tyder imidlertid på, at billedet er ved at ændre sig. I forbindelse med implementeringen af 3. udgave af National håndbog for den politimassige indsats $i$ forbindelse med fodboldkampe i efteråret 2011 lægger Rigspolitiet således op til, at der skal laves en tredages uddannelse baseret på erfaringerne fra den såkaldte eventbetjentuddannelse, som handler om dialogbaseret politiarbejde i forbindelse med håndteringen af masseforsamlinger.

Denne artikel har til formål at beskrive eventbetjentuddannelsen og baggrunden herfor. Uddannelsen er resultatet af et flerårigt samarbejde mellem det tidligere Institut for Idræt (nu Sektion for Idræt), Aarhus Universitet og Østjyllands Politi. Samarbejdet blev indledt, da Østjyllands Politi i sommeren 2007 kontaktede Institut for Idræt med henblik på at få et udefrakommende og forskningsbaseret blik på politiets håndtering af fodboldfans. ${ }^{6}$

\section{National håndbog for den politimassige indsats $i$ forbindelse med fodboldkampe - kimen til forandring}

I juni 2008 blev førnævnte National håndbog for den politimassige indsats i forbindelse med fodboldkampe (»fodboldhåndbogen«) sendt ud til landets politikredse. Strategien var et led i Flerårsaftalen for politi- og anklagemyndigheden 2007-2010:

I Flerårsaftalen for politiet og anklagemyndigheden 2007-2010 er det anført, at politiet og anklagemyndigheden i de kommende år gradvist vil fă langt bedre muligheder for at gennemføre målrettede indsatser på særligt prioriterede områder, herunder i forhold til »fodboldbøller«. Det fremgår i den forbindelse af Flerårsaftalen, at fodboldbøller ikke skal »have lov til at skabe uro og utryghed omkring fodboldkampe. Der er behov for en intensivering og nytænkning af indsatsen ? $^{\top}$

Ændringerne i håndteringen af fodboldkampe bestod bl.a. i, at der ikke længere skulle være uniformeret politi på stadion. Men den mest markante ændring bestod $\mathrm{i}$, at betjentene i forbindelse med fodboldkampe skulle bære gule veste (som udgangspunkt) oven på patruljeuniformer, når de befandt sig omkring stadion. Ideen med de gule veste stammer fra England og formålet er, at indsatsen skal være synlig, tryghedsskabende og forebyggende. Hvor man hidtil i vid udstrækning havde fæstet lid til det mobile indsatskoncept, blev der med »fodboldhåndbogen« nu lagt vægt på en indsats, hvor små enheder på 2-3 personer skulle foretage "gående sektorpatrulje« med henblik på at være imødekommende og dialogsøgende over for alle tilskuere. Kom det til uroligheder, skulle man iværksætte en afpasset og målrettet indsats mod de uroskabende personer, uden at det påvirkede de øvri- 
ge tilskuere. Både den gule vest og den dialogsøgende »sektorpatrulje« var nye tiltag i forhold til politiets gængse adfærd overfor fodboldfans ved højrisikokampe. Man kan derfor sige, at kimen til forandring var lagt med den nye fodboldhåndbog.

I forbindelse med implementeringen stødte håndbogen imidlertid på en række barrierer. ${ }^{8}$ Blandt andet var der en høj grad af modstand mod den gule vest, som en del betjente oplevede som en latterliggørelse af deres virke (til dels på grund af ligheden med skolepatruljeuniformer). Men samtidig har det også vist sig lettere sagt end gjort at få danske politibetjente til at påtage sig rollen som »gående sektorpatrulje« og være dialogsøgende og imødekommende i håndteringen af masseforsamlinger. ${ }^{9}$ For Østjyllands Politi kom erkendelsen af dette for alvor i forbindelse med rapporten Forebyggelse af fodboldoptøjer - observationer af Østjylland Politis arbejde. ${ }^{10}$ Rapporten konkluderer blandt andet, at mangel på kodekendskab, dialog og et forfejlet risikobillede i visse tilfælde førte til unødvendige konfrontationer. Alt sammen områder som en dialogbaseret indsats efter alt at dømme ville kunne afværge eller mindske omfanget af. På baggrund af undersøgelsen traf Østjyllands Politi derfor den strategiske beslutning at indgå et samarbejde med Institut for Idræt omkring opbygningen af en forskningsbaseret uddannelse, som kunne give betjentene værktøjer til håndteringen af større masseforsamlinger. Centralt for uddannelsen står områderne dialog, kodekendskab, facilitering og et dynamisk afstemt risikobillede, som løbende danner grundlag for afviklingen af den politimæssige operation. Uddannelsen knytter an til den internationale forskning i massepsykologi, som har været dominerende inden for de sidste cirka 25 år, hvilket følgende afsnit beskriver nærmere.

\section{Den misforståede masse}

Eventbetjentuddannelsen er baseret på forskning i masseforsamlinger. Nedenfor gennemgås tre af de væsentligste hovedretninger i den tidlige massepsykologiske forskning. ${ }^{11}$

En tidlig og sejlivet teoridannelse om reaktioner hos mennesker, der befinder sig i en folkemasse, blev udfoldet af den franske socialpsykolog Gustave Le Bon, som i 1895 udgav bogen La Psychologie des Foules (Massernes Psykologi, 2005). En af bogens hovedpointer er, at bliver man først opslugt af massen, tager primitive instinkter over på bekostning af fornuften. Ens dømmekraft forsvinder ganske enkelt, når man bliver grebet af stemningen. Samtidig er massen svær at kontrollere, ja stort set utilregnelig. ${ }^{12}$ Hvis massens leder(e), »agitator(er)«, har voldelige intentioner, vil han/de ofte forsøge at opildne til vold. Sandsynligheden for, at det lykkes, er stor, al den stund massen så at sige smitter den enkelte med 
sine farlige egenskaber, så alle tænker og handler ens. Når individet bliver en del af en masse og giver efter for undertrykte instinkter, kommer det til at opleve en følelse af uovervindelig magt. Massesuggestion fører med andre ord til, at individets personlighed undertrykkes til fordel for nye forestillinger fremlagt af massens leder(e).

Le Bons idé om massen, den såkaldte smitteteori (contagion theory), og de teorier, der bygger på den idé, er blevet anfægtet af flere kritikere, der har afvist såvel tanken om, at massen har sit eget liv uafhængigt af individernes tanker og intentioner såvel som ideen om det irrationelle. Et andet kritikpunkt har været, at teorien mangler empirisk understøttelse. En række forskere har endvidere sat spørgsmålstegn ved individernes tilsyneladende ensartede adfærd i massen. ${ }^{13}$

Inspireret af Le Bon udviklede socialpsykologen Floyd Allport i 1920'erne konvergensteorien (convergence theory), som siden blev videreudviklet af Neal Miller og John Dollard. ${ }^{14}$ Konvergensteorien hævder, at masseadfærd ikke er et produkt af massen selv, men så at sige føres ind i massen. Således opstår masseadfærd, fordi ligesindede individer søger sammen og konstituerer massen. Mens smitteteorien altså hævder, at massen får folk til at handle anderledes, end de ville gøre på individuelt plan, hævder konvergensteorien, at folk, der ønsker at handle på en bestemt måde søger sammen med ligesindede og former en masse. Hvorvidt en person vælger at deltage i en kollektiv begivenhed afhænger af, om personen opfatter begivenheden som ønskværdig eller uhensigtsmæssig. Graden af involvering afhænger derfor af graden af individets følelsesmæssige prædisposition. Anonymiteten i massen inviterer individerne til at deltage i kollektive handlinger, der normalt fordømmes af det omgivende samfund. ${ }^{15}$ Konvergensteorien hævder, at masseadfærd som sådan ikke er irrationel, men at masseadfærden er udtryk for værdier og forestillinger, som allerede eksisterer i samfundet. Masseadfærden er ifølge konvergensteorien således et rationelt produkt af rationelle værdier. Konvergensteorien er blevet kritiseret for ikke at kunne forklare dynamikker i massen såsom adfærdsmæssige skift i løbet af en massebegivenhed eller fordelingen af roller blandet individerne. ${ }^{16}$

Herbert Blumer byggede i 1950'erne videre på Le Bons teori. Han fastholdt tanken om massens irrationelle adfærd og individets tab af fornuft og selvstændige tankevirksomhed, men tilføjede begrebet cirkulær reaktion, hvilket vil sige, at adfærd, der først er udført tilfældigt, aktivt gentages i en fortløbende proces, hvormed adfærden intensiveres. ${ }^{17}$ Et andet bud på masseadfærd, der ligeledes blev fremsat i 1950'erne, er den såkaldte emergent norm theory, som Ralph Turner og Lewis Killian stod bag. Ifølge Turner og Killian begynder masser som mindre grupper sammensat af folk med forskellige interesser og motiver. Turner 
og Killian anser ikke masseadfærden som værende uden normer, men individerne i massen skaber normerne i fællesskab og spreder dem i massen via social interaktion. Normerne i en masse kan være vage og skifte undervejs i et forløb. Nye normer accepteres som »normale«, fordi de vurderes i forhold til en given situation snarere end i forhold til en a priori forståelse af normal adfærd. Mens deltagerne givetvis har en forudgående opfattelse af rigtige handlinger, kan deres syn på de givne omstændigheder i forbindelse med en specifik begivenhed hjælpe dem med at rationalisere normbrydende adfærd. Når folk således deltager i normbrydende kollektive handlinger, gør de det, fordi adfærden giver mening i lyset af den situation, de befinder sig i. Når en særlig situation opstår, sker det $\mathrm{i}$ nogle tilfælde, at folk mangler en rettesnor for, hvordan de skal reagere og opføre sig. De ser derfor på, hvad andre, især markante personer (keynoters), gør og indretter og vurderer deres egen adfærd herefter. ${ }^{18}$ Turner og Killian er blevet kritiseret for at give de nonverbale processer for lidt opmærksomhed. ${ }^{19}$ Deres teori er ligeledes blevet kritiseret for at være for orienteret mod socialitet på mikroniveau, hvor makroniveauet og den bredere samfundsforståelse er tilsidesat til fordel for den aktuelle påvirkning på mikroniveauet. Men deres bidrag har dog været værdifuldt, idet de har formået at påvise masseadfærdens såvel rationelle som normative karakter, hvilket nu er den dominerende tanke inden for forskningen på området. $^{20}$

På trods af kritik gennem årtier fra socialpsykologisk forskning, har især den Le Bon-inspirerede opfattelse af masserne bidt sig fast og holdt ved op gennem det 20. århundrede og ind i det 21. århundrede. Engelske forskere har f.eks. identificeret det Le Bon-inspirerede syn på massen i kursusmateriale, som politiet $\mathrm{i}$ England og Wales i dag benytter sig af i forbindelse med kurser i public order policing. ${ }^{21}$ Det til trods for, at en lang række forskere gennem mere end tyve år har påvist, at det er et forfejlet syn på massen, der risikerer at blive en selvopfyldende profeti. ${ }^{22}$ Har man først lagt sig fast på massens utilregnelighed, den sunde fornufts forsvinden, aggressionen og de primitive instinkter, er der ikke langt til, at en mindre episode risikerer at eskalere som følge af en optrapning fra politiets side $\mathrm{i}$ forsøget på at inddæmme og hindre massen $\mathrm{i}$ at udfolde sin formodede iboende tendens til at gå amok. Studier af demonstrationer og fodboldkampe har gentagne gange demonstreret denne logik. ${ }^{23}$ Inden for fodboldområdet er et af de mest kendte eksempler EM i 2000, hvor Holland og Belgien delte værtskabet. Holland valgte en friendly but firm strategi, der havde sigte på negotiated management. ${ }^{24}$ Tanken var at fremme en karnevalsagtig stemning, hvor politiet samtidig skulle være håndfaste $\mathrm{i}$ forhold til eventuel indgriben og kommunikation af acceptable grænser. Belgien derimod lagde sig fast på en konfrontativ strategi, 
som blev udfoldet, da en mindre episode i den belgiske by Charleroi eskalerede som følge af, at politiet greb ind med tåregas, vandkanoner og politistave. 965 engelske fans blev anholdt. Efterfølgende blev cirka halvdelen deporteret til England, herunder et amerikansk ægtepar, der befandt sig på det forkerte sted på det forkerte tidspunkt. $^{25}$

Ser man nærmere på begivenheden havde der op til EM - som altid forud for en større slutrunde - været en massiv mediefokus på, at den engelske hooliganisme, the English Disease, ville invadere Holland og Belgien. Undersøgelser har siden vist, at det belgiske politi havde en forventning om, at de stod over for en horde af utilregnelige engelske fans ${ }^{26}$ Blandt andet pegede de adspurgte betjente på, at megen alkoholindtagelse og højtråbende engelske fans ville være et sikkert tegn på, at hooligans var på færde, og at sandsynligheden for at tingene ville eskalere derfor var stor. ${ }^{27}$ Kender man til engelsk fankultur, ved man, at der bliver drukket en del, men det er ikke ensbetydende med, at det udarter sig til hooliganisme. Mens begivenhederne i Charleroi kan betegnes som en selvopfyldende profeti, blev der til sammenligning kun anholdt 6 engelske fans i Holland i forbindelse med højrisikokampen mellem England og Portugal i Eindhoven - en kamp som England tabte 2-3 efter at have ført 2-0. Til kampen havde politiet identificeret kendte engelske kategori $\mathrm{C}$ supportere, dvs. hooligans, men deres tilstedeværelse er ikke ensbetydende med, at de har voldelige intentioner, hvilket både britisk og hollandsk politi vidste. Samtidig er det værd at bemærke, at de 6 anholdelser ikke havde med voldelige episoder at gøre.

\section{Det forskningsbaserede grundlag for eventbetjentuddannelsen}

Nogle af de helt centrale skikkelser bag forskningen i politiets håndtering af demonstrationer og fodboldkampe er de britiske forskere Stephen Reicher, Clifford Stott og John Drury, der har stået bag udviklingen af The Elaborated Social Identity Model (ESIM) ${ }^{28}$ Det er viden fra denne forskningstradition, der udgør det teoretiske fundament for eventbetjentuddannelsen.

ESIM tager udgangspunkt i, at en masse ikke består af en samlet enhed. Derimod er der tale om, at en masseforsamling udgøres af en række forskellige grupperinger, der har forskellige normer og værdier. Individet ser sig selv som en del af den gruppe, det indgår i og danner socialt fællesskab med. Handlen sker derfor på baggrund af det sociale tilhørsforhold, idet individet tilpasser sig gruppens normer, mens gruppen definerer sig i opposition til andre, f.eks. voldelige, grupper. Denne identifikation kan dog forandres, hvis situationen ændres. Studier har vist, at ellers fredelige personer søger støtte hos erklærede voldelige i situationer, hvor de finder politiets fremfærd illegitim. ${ }^{29}$ Studier af risiko og risikohåndtering 
har ligeledes påvist, at der er større sandsynlighed for optøjer i de situationer, hvor politiet har anlagt en højprofil (dvs. er massivt til stede iført indsatsuniformer), mens modparten derimod ikke opfatter situationen som særlig risikofyldt, hvilket ofte modsvarer den aktuelle risiko i situationen.$^{30}$ I situationer, hvor politiet anlægger en konfrontativ og udifferentieret indsats, uden at modparten oplever situationen som risikofyldt, opfattes politiets indsats som disproportional og illegitim. Modsat opfatter modparten politiets indsats som legitim i de tilfælde, hvor de oplever, at den er afbalanceret og tilpasset situationen. I disse tilfælde har man desuden kunnet observere en øget selvjustits blandt deltagerne i masseforsamlingerne, som det eksempelvis er påvist i forbindelse med demonstranter og fodboldfans. ${ }^{31}$ Demonstranter og fodboldtilskuere har med andre ord selv i en række sammenhænge sørget for at dæmpe gemytterne, når der har været noget under opsejling, fordi dialogen mellem hhv. demonstranter eller fodboldfans og politi har været god. Man kan derfor tale om, at politiet har haft succes med at informere begivenhedens deltagere om, hvad deres hensigt er, ligesom deltagerne på deres side har været villige til at give politiet de nødvendige informationer for, at begivenheden kan afvikles uden dramatik. Er der alligevel optræk til optøjer, vil det som oftest være muligt at målrette indsatsen efter de faktiske uromagere som følge af den viden om forsamlingens sammensætning, som dialogen har tilvejebragt. Samtidig ser man ofte i situationer som disse, at personer med voldelige intentioner marginaliseres og således ikke får held med at alliere sig med erklærede ikke-voldelige, hvormed risikoen for konflikt mindskes betragteligt.

Ovenstående indsigter fra massepsykologisk forskning er en integreret del af den internationale fodboldhåndbog Handbook with recommendations for international police cooperation and measures to prevent and control violence and disturbances in connection with football matches with an international dimension: ${ }^{32}$ 


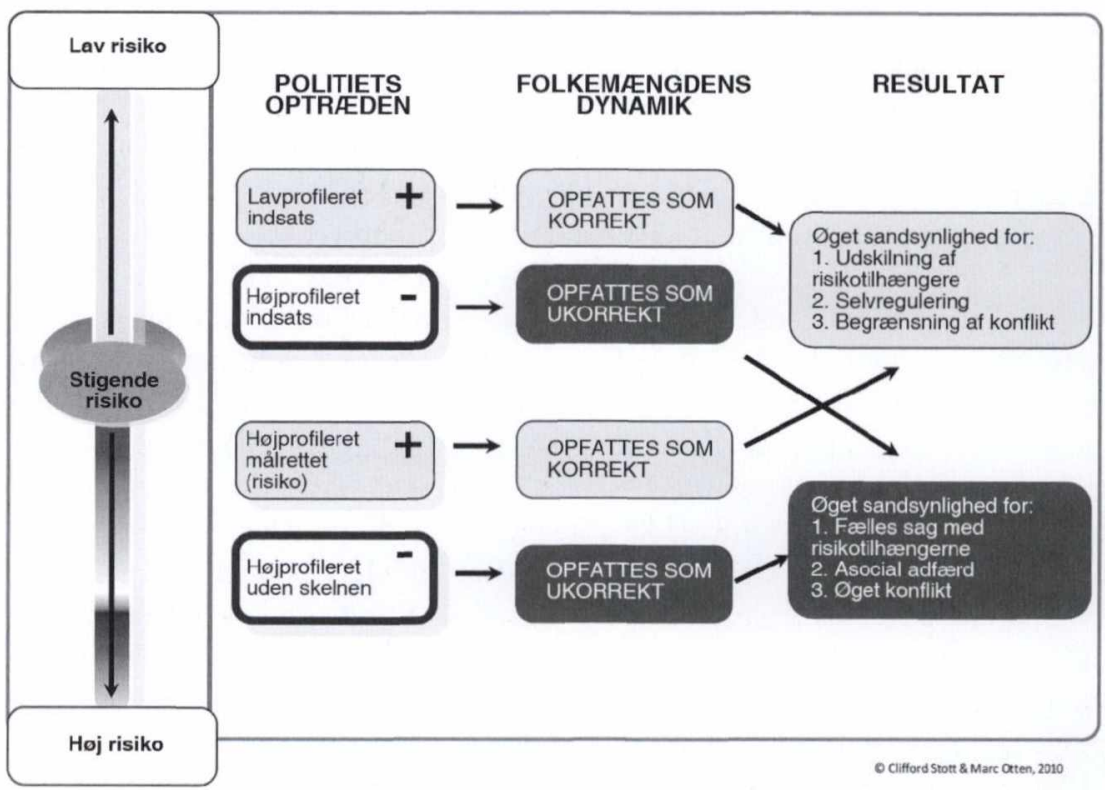

På europæisk plan har denne forskning nu medvirket til etableringen af et fælleseuropæisk forskningsbaseret uddannelsesprogram for politiet, det såkaldte Pan European Football Policing Training Project, som er støttet af Europakommissionen og det europæiske fodboldforbund UEFA. ${ }^{33}$ Eventbetjentuddannelsen lægger sig således i kølvandet på en paneuropæisk strømning af forskningsbaseret politiarbejde, der sætter dialogen i højsædet.

\section{Inspiration fra svensk dialogpoliti}

Eventbetjentuddannelsen har ligeledes hentet inspiration fra svensk dialogpoliti, som blev etableret som følge af hændelserne i forbindelse med EU topmødet i Gøteborg i 2001, hvor voldsomme sammenstød mellem demonstranter og politi fandt sted. Håndteringen af topmødet førte til kritik fra Göteborgskommittén, som efterfølgende blev nedsat. Komiteen kritiserede politiet for ikke i tilstrækkelig grad at have gjort brug af dialogens muligheder både før, under og efter begivenhederne. $^{34}$

Svensk politi iværksatte på den baggrund i 2004 projektet Special Police Tactics (SPT), som havde til formål at udvikle fælles taktiske retningslinjer i håndteringen af masseforsamlinger. ${ }^{35}$ Overordnet set tager SPT udgangspunkt i borger- 
nes rettigheder (forsamlingsfrihed, ytringsfrihed etc.) som grundlag for transparent politiarbejde. Politiets opgave er defineret ud fra principper om at facilitere "facilitation« borgernes legitime intentioner samt at søge dialog »dialogue « både før, under og efter en begivenhed. Desuden er et »modpartsperspektiv« »counterpart perspective « indlejret i taktikken, idet politiet ved enhver indsats skal overveje »modpartens « reaktion på en given indsats. Dette kræver selvsagt en forståelse for modpartens kultur og værdier, hvilket også har bevirket, at betjente indenfor svensk dialogpoliti løbende opkvalificerer sig på universitetsniveau for at få den nødvendige baggrundsviden til bedre at kunne håndtere politiske og religiøse konflikter. Teoretisk er politiets håndtering af masseforsamlinger forankret $\mathrm{i}$ samme forskningsmodel som ovenfor beskrevet, hvilket skal medvirke til at sikre, at politiet iværksætter en differentieret »differentation« indsats, hvor der kun sættes ind overfor de identificerede uromagere frem for mod hele folkemængden. Afledt af tanken om en transparent politiindsats arbejder politiet med en taktik, hvor politiet anvender signaler »signal value « til at vise politiets opfattelse af risiko $\mathrm{i}$ en given situation. ${ }^{36}$ Endelig har man forsøgt at harmonisere det interne sprogbrug i forhold til beskrivelse af stemningen »state i en forsamling for at undgå faren for en misfortolkning af stemningen i en gruppe. ${ }^{37}$

Svensk dialogpoliti har oplevet megen modstand internt $\mathrm{i}$ organisationen. Nogle af kollegerne ser dem nærmest som forrædere, fordi deres arbejde består i at føre dialog med »modparten «. Denne dialog kolliderer med politibetjentes traditionelle sort/hvide opfattelse, hvor grupper og individer enten opfattes som gode eller onde (eller på dansk: Hr. og Fru Danmark versus »røvhullerne «). ${ }^{38}$ Men der er også en mere grundlæggende ændring indlejret, som forstærker modstanden, idet der implicit i dialogkonceptet er et skifte i politiets rolle fra »crime fighters « til »peace keepers« og derved rører man ved den enkelte politibetjents opfattelse af sig selv som politimand. ${ }^{39}$

Nedenfor beskrives eventbetjentuddannelsen, som den i store træk forløb i forbindelse med afvikling af de to første kurser, der blev afviklet i 2010. Ved det tredje kursus, afviklet i 2011, var der skåret ned i antallet af undervisningsdage. Uddannelsen blev evalueret af Rigspolitiet med sigte på eventuelt at lade uddannelsen tjene som grundlag for en fremtidig uddannelsesstrategi på området.

\section{Uddannelsens opbygning og indhold}

Eventbetjentuddannelsen kan beskrives som en knowledge transfer activity, der har haft sigte på at integrere ovenstående forskning og resultaterne af en observations- og en interviewundersøgelse foretaget hos Østjyllands Politi i praksis. Det har været et centralt formål at give kursisterne en forståelse af vigtigheden i at 
kunne forstå »modpartens« kultur. Undervisningen var primært baseret på cases til illustration af kernetemaerne i forskningen. Uddannelsen var ikke baseret på kursisternes læsning af artikler o.lign. Det blev fravalgt, eftersom det er erfaringen, at politifolk ikke er vant til at læse hverken korte eller længere tekster. ${ }^{40}$ Hvor man således ofte vil lave et undervisningsforløb bygget op omkring et pensum, blev der i stedet lagt vægt på at forsøge at bringe praksis ind i undervisningen gennem virkelighedsnære cases, der nøje afspejlede de enkelte læringsmål for hvert modul i kurset.

Undervisningen introducerede forskningstraditionen bag og demonstrerede samtidig positive erfaringer fra andre lande, hvor man i forbindelse med afvikling af større events har forsøgt lignende tilgange til håndtering af masseforsamlinger (f.eks. EM 2000 i Holland/Belgien, EM 2004 i Portugal og det svenske dialogpoliti). I tillæg dannede en række feltobservationer foretaget rundt om i Danmark med dertilhørende videocases grundlag for praksisnære drøftelser. På det indledende internat (del 1-2) dannede undervisningen afsæt for en diskussion af politiets muligheder og barrierer for at inkludere forskningen i praksis. I forbindelse med undervisningen blev der anvendt foredragsholdere fra svensk dialogpoliti og S-100 fra Københavns Politi, som er en specialenhed, der arbejder ud fra en dialogbaseret tilgang til de københavnske risikofans, herunder hooligans.

Del 3 havde til formål at integrere erfaringerne fra del 1 og 2 i en konkret operationsplan, der var rettet mod en aktuel begivenhed, som kursisterne skulle varetage afviklingen af. Denne del havde også deltagelse af foredragsholdere fra relevante parter. DSB introducerede således deres dialogkoncept, som siden 2008 har været en stor succes i forhold til håndteringen af risikofans. Stadionansvarlige var ligeledes involveret med henblik på at give indblik i håndteringen af begivenhederne inde på stadion. Og sidst men ikke mindst gav fodboldfans en række øjenåbnende foredrag om deres syn på politiets håndtering af dem gennem en række konkrete eksempler, herunder videocases. På del 3 er det samtidig værd at bemærke, at modulet sigtede på at give deltagerne på eventbetjentuddannelsen en højere grad af indflydelse, end de normalt er vant til, hvilket blandt andet skete for at bryde med det mobile indsatskoncepts hierarkisk militære struktur, der ikke lægger op til individuel beslutningstagen på menigt niveau. Samtidig sigtede uddelegeringen af ansvar på et øget ejerskab for konceptet, hvilket har haft betydning for dets succes. På uddannelsens 4 . del bestod opgaven $\mathrm{i}$ at afvikle en risikokamp i den danske superliga i fodbold på baggrund af eventkonceptet. Del 5, som blev afholdt en til to uger efter del 4 , blev brugt til at evaluere kampdagen. I den forbindelse blev der dels foretaget kritisk selvevaluering, en forskningsbaseret evaluering, som inkluderer interviews med involverede fodboldfans, DSB og sik- 
kerhedsansvarlige på stadion samt videomateriale fra kampen. Efter afvikling af de to første kurser blev der desuden afholdt en fælles evalueringsdag for samtlige kursister, der havde været gennem forløbet. Denne dag havde til formål at reflektere over de forskellige holds erfaringer med henblik på at komme til en samlet forståelse af best practice.

\section{Uddannelsens opbygning}

Del 1-2 (internat): Introduktion til den bagvedliggende forskningstradition, cases til belysning af problemstillinger forbundet med håndtering af masseforsamlinger

Del 3: Forberedelser til kampdagen, foredrag med udefrakommende aktører

Del 4: Kampdag

Del 5: Evaluering af kampdagen

Erfaringerne fra de tre afviklede kurser har været yderst positive. Uddannelsen har ført til en højere grad af refleksion blandt politifolk omkring egen praksis. Fra uddannelsens start og frem mod kampdagen udviklede diskussionerne sig fra et fokus på det mobile indsatskoncept til et mere differentieret syn på dialog og dialogens muligheder som selvstændigt redskab til håndtering af masseforsamlinger og som integreret del af det mobile indsatskoncept. Hvad fansene angår, har de i forbindelse med evalueringerne meldt yderst positivt tilbage på deres første møde med det nye koncept. Højrisikokampene er således blevet afviklet uden nævneværdige problemer.

Undervejs i artiklen har ordet »modpart« været anvendt. Det er politiets sædvanlige måde at omtale en gruppe af mennesker, som de er sat til at håndtere. Men i takt med at dialogen mellem eventbetjentene og de pågældende deltagere i masseforsamlingerne intensiveres, giver billedet af en »modpart« ikke længere mening. I forbindelse med evalueringerne har vi kunnet se, at opfattelsen af et »os « mod et »dem « er trådt i baggrunden til fordel for et nuanceret billede af den store forsamling, som politiet har til opgave at håndtere på en måde, hvor man undgår at tilsidesætte borgernes grundlæggende rettigheder.

\section{Afrunding}

Målsætningen med uddannelsen er, at der med en dialogbaseret tilgang til håndtering af masseforsamlinger opstår færre risikosituationer. Uddannelsen har implikationer for politiets øvrige koncepter. Et væsentligt kritikpunkt rejst af politifolk har været, at »dialogkonceptet« ikke har været fremlagt som et færdigudviklet koncept og derfor ikke har kunnet udgøre en erstatning for det mobile indsatskoncept. Kritikken skal ses i lyset af, at det mobile indsatskoncept, som man har 
været vant til, er særdeles deltaljeret beskrevet i tidligere chefpolitiinspektør Kai Vittrups lærebøger Strategi (2002a) og Operation (2002b). At konceptet ikke er færdigudviklet skal ses i sammenhæng med, at det på et mere overordnet niveau bør integreres i den mobiltaktiske uddannelse. Udfordringen består således i at udvikle et koncept, som kan fungere i sig selv, men som ligeledes er fuldt integreret som taktisk mulighed i det mobile indsatskoncept. Eventbetjentuddannelsen er i den henseende blot et første skridt på vejen mod et dialogbaseret indsatskoncept.

Der forestår ligeledes en udfordring $i$ at tilpasse og udvikle projektet ud fra de reaktioner, som politiet møder. Når politiet bryder markant med tidligere adfærd, kan det afstedkomme en skepsis. Desuden har der været kritiske røster blandt fodboldfans, som har oplevet politiets indsats som værende for pædagogisk og omklamrende. Endeligt har indsatsen bevirket, at politiindsatsen kredsene imellem blev mere uensartet, stik imod hensigterne med National håndbog for den politimassige indsats i forbindelse med fodboldkampe. Disse forhold skal der tages højde for i det videre arbejde med et dialogbaseret indsatskoncept, men erfaringerne indtil nu tyder på, at det er den rigtige vej at gå på det rigtige tidspunkt set i forhold til den foreliggende forskning på området og udviklingen i det danske samfund generelt.

I det svenske dialogpoliti har man valgt så vidt muligt at undgå, at dialogbetjentene anvender andre magtmidler end dialog. Skal der bruges andre midler, trækkes betjentene ud af situationerne. Med eventbetjentene forsøger man at gøre det samme i det omfang, der er en taktisk reserve klædt på til fysisk magtanvendelse i nærheden. Filosoffen Adam Diderichsen fra Rigspolitiets Videnscenter, som har været med til at evaluere uddannelsen, fremhæver følgende i sin bog Etik for politifolk:

Ved at have specialuddannet politi, som kan tage sig af dialog, henholdsvis fysisk magtudøvelse, kan man både minimere anvendelsen af fysisk magt og gøre den mere effektiv, fordi man kan målrette den mod de mennesker, der udgør problemets kerne, snarere end at skyde med spredehagl og ende med en konfrontation med en hel folkemængde. ${ }^{41}$

Dansk politi har efter evalueringen af uddannelsen besluttet at lave et tredages kursus baseret på erfaringerne fra eventbetjentuddannelsen. Den nye uddannelse bliver således landsdækkende. Modsat den paneuropæiske uddannelse har Rigspolitiet valgt ikke at gøre den landsdækkende uddannelse forskningsbaseret. Som en følge heraf er det kun erfaringerne fra Østjyllands Politi, der har interesse for den paneuropæiske uddannelse. 


\section{Noter}

1. Sektion for Idræt, Aarhus Universitet

2. Beretning i henhold til lov nr. 389 af 22. maj 1996 om Undersøgelse af Nørrebrosagen, s. 170.

3. Vittrup 2002a; 2002b

4. Rasmussen \& Havelund 2010

5. Rasmussen \& Havelund 2010

6. At denne type henvendelse og det efterfølgende samarbejde ikke er hverdagskost i Dansk Politi kan man bl.a. læse af Gerhard Hanak og Veronika Hofingers artikel »Police Science and Research in the European Union«, hvori 26 EU-landes forhold mellem forskning og politiet er blevet analyseret (Hanak \& Hofinger 2006). Heraf fremgår det, at Danmark er et af de europæiske lande, hvor der foregår mindst samarbejde mellem forskning og politiets virke.

7. Her gengivet efter National håndbog for den politimcessige indsats i forbindelse med fodboldkampe, 2. udgave (2009), s. 2.

8. Rasmussen \& Havelund 2010

9. Rasmussen \& Havelund 2010

10. Rasmusen, Havelund \& Tranegaard Andersen 2009

11. For en nærmere gennemgang af massepsykologien, se Reicher (2001).

12. Le Bons arbejde inspirerede folk som Mussolini og Hitler, idet de så muligheder for, via en forståelse for massernes psykologi, at kontrollere stemningen i masserne og vender den til egen fordel.

13. McPhail 1991; Turner 1964; Smelser 1963; Berk 1974

14. Allport 1924; Miller \& Dollard 1941

15. Miller \& Dollard 1941

16. Turner 1964

17. Blumer 1951

18. Turner \& Killian 1957

19. Wright 1978

20. Hoggett \& Stott 2010

21. Hoggett \& Stott 2010

22. Reicher 2011

23. Stott \& Pearson 2007

24. Adang \& Cuvelier 2001

25. Stott \& Pearson 2007

26. Stott 2003

27. Stott 2003

28. Se f.eks. Stott \& Reicher 1998; Drury et al. 2003; Reicher et al. 2004; Reicher 2011

29. Reicher et al. 2004, Stott \& Reicher 1998

30. Stott \& Adang 2009

31. Stott \& Pearson 2007

32. EU Council 2010

33. I projektgruppen bag det »Pan European Football Policing Training Project $\ll$, som ledes af det engelske politi, indgår bl.a. en lang række landes politistyrker, CEPOL, UEFA samt 
forskere. Aarhus Universitet har deltaget i uddannelsen af ukrainske politi- og sikkerhedsfolk med henblik på EM 2012.

34. SOU 2002

35. Holgersson 2010

36. En tilsvarende tankegang har man bl.a. set i forbindelse med EM i fodbold i Portugal, hvor bypolitiet arbejdede med fire stadier for politiindsats (Stott et. al 2007).

37. Holgersson \& Knutsson 2011

38. Holgersson \& Knutsson 2011; Holmberg 1999

39. Sørensen 2010

40. Rasmussen \& Havelund 2010

41. Diderichsen 2011: 138

\section{Litteratur}

Adang \& Cuvelier (2001). Policing Euro 2000. International police co-operation, information managenemt and police deployment. Police Academy of the Netherlands, Apeldoorn.

Allport (1924). Social Psychology. Houghton Mifflin, Boston.

Berk (1974). Collective Behavior. Brown, Iowa.

Blumer (1951). »Collective Behavior«. In: Lee (ed.) New Outline of the Principles of Sociology. Barnes and Nobles, New York.

Diderichsen (2011). Etik for politifolk. Samfundslitteratur, Frederiksberg.

Drury, Stott \& Farsides (2003), »The Role of Police Perceptions and Practices in the Development of »Public Disorder«, Journal of Applied Social Psychology, 2003, 33, 7, pp. 14801500 .

EU Council Resolution (2010). Handbook with recommendations for international police cooperation and measures to prevent and control violence and disturbances in connection with football matches with an international dimension, in which at least one Member State is involved.

Hanak \& Hofinger (2006). »Police Science and Research in the European Union«. In: Fehérváry, Hanak, Hofinger \& Stummvoll (eds.). Theory and Practice of Police Research in Europe. Contributions and Presentations from CEPOL Police Research \& Science Conferences 2003-2005, CEPOL Series No. 1, 51-66.

Hoggett \& Stott (2010). »Crowd psychology, public order police training and the policing of football crowds«. Policing: An International Journal of Police Strategies \& Management. Vol. 33 No. 2, 2010, pp. 218-235.

Holgersson \& Knuttson (2011). »Dialogue Policing: A Means for Less Crowd Violence?«. In: Madensen \& Knutsson (red.). Preventing Crowd Violence. Crime and Prevention Studies, vol 26. Lynne Rienner Publishers, London.

Holgersson (2010). Dialogue Police - Experiences, observations and opportunities. RPS Rapport 2010:4 Swedish National Police Board.

Holmberg (1999). Inden for lovens rammer. Gyldendal, København.

Le Bon (1895/2005). Massernes Psykologi. Forlaget Helikon.

McPhail (1991). The Myth of the Madding Crowd. de Gruyter, New York.

Miller \& Dollard (1941). Social Learning and Imitation. Yale University Press, New Haven. 
National håndbog for den politimcessige indsats $i$ forbindelse med fodboldkampe, 2. udgave (2009)

Rasmussen \& Havelund (2010). Forebyggelse af fodboldoptøjer - en interviewundersøgelse. Justitsministeriets hjemmeside.

Rasmussen, Havelund \& Tranegaard Andersen (2009). Forebyggelse af fodboldoptøjer - Observationer af Østjyllands Politis arbejde. Kulturministeriets Udvalg for Idrætsforskning.

Reicher (2001). »The psychology of crowd dynamics«. In: Hogg \& Tindale (eds.) Blackwell handbook of social psychology: Group processes, s. 182-208. Oxford: Blackwell.

Reicher (2011). »From Crisis to Opportunity: New Crowd Psychology and Public Order Policing Principles«. In: Madensen \& Knutsson (eds.) Preventing Crowd Violence, s. 7-24, London: Lynne Rienners Publishers, Inc.

Reicher, Stott, Cronin and Adang (2004). »An integrated approach to crowd psychology and public order policing «, Policing: An International Journal of Police Strategies \& Management, 27, 558-572.

Smelser (1963). Theory of Collective Behavior. Free Press, New York.

SOU (2002). Statens offentliga utredningar, Göteborg 2001, Betänkande från Göteborgskommittén, Statens offentliga utredningar 122, Fritzes förlag, Stockholm.

Stott \& Adang (2009). Understanding and managing risk - Policing Football Matches with an International Dimension in the European Union. Bavnebanke Press.

Stott \& Pearson (2007). Football »Hooliganism«. Policing and the War on the »English Diseaser. Pennant Books.

Stott \& Reicher (1998). »How Conflict Escalates: The Inter-Group Dynamics of Collective Football Crowd »Violence««, Sociology, vol. 32, no. 2.

Stott (2003). »Police expectations and the control of English soccer fans at »Euro $2000 \ll$. Policing: An International Journal of Police Strategies and Management. Vol. 26 No. 4. 640655 .

Stott, Adang, Livingstone \& Schreiber (2007). Policing, Crowd Dynamics and Public Order at Euro2004. A report to the Home Office on the project »A European study of the interaction between police and crowds of foreign nationals considered to pose a risk to public order «.

Sørensen (2010). »Akademikere og politiet - kampen mellem teori og praksis«. Nordisk Tidsskrift for Kriminalvidenskab, 3, 268-274.

Turner \& Killian (1957). Collective Behavior. New Jersey, Prentice-Hall.

Turner (1964). »Collective Behavior«. In: Faris (ed.) Handbook of Modern Sociology. Rand McNally, Chicago.

Vittrup (2002a). Strategi, 3. udgave, Københavns Politi.

Vittrup (2002b). Operation, 3. udgave, Københavns Politi.

Wright (1978). Crowds and Riots. Sage, California. 